\title{
Two faces of peripherality: labour markets, poverty, and population dynamics in Hungary and Czechia*
}

Gergely Tagai This study investigates socioeconomic peri-

Hungarian Academy of Sciences Centre for Economic and Regional

Studies

Institute for Regional Studies,

Hungary

E-mail: tagai@rkk.hu

Josef Bernard

Czech Academy of Sciences

Institute of Sociology, Czechia

E-mail: josef.bernard@soc.cas.cz

Martin Šimon

Czech Academy of Sciences

Institute of Sociology, Czechia

E-mail: martin.simon@soc.cas.cz

Bálint Koós

Hungarian Academy of Sciences Centre for Economic and Regional

Studies

Institute for Regional Studies,

Hungary

E-mail:koosb@rkk.hu

Keywords: peripheralisation,

Central Europe,

labour market,

socio-spatial inequality pherality in Hungary and Czechia. Despite the current attention devoted to peripheries in post-communist societies, the authors argue that there is a lack of data-driven international comparisons of the socio-spatial outcomes of peripheralisation processes. In the study, the situations in Hungary and Czechia are compared to assess the validity of peripheralisation as a mutually reinforcing economic, social and demographic decline specifically affecting rural areas. First, the concentration of social problems such as unemployment and poverty is examined in economically weak rural areas. Second, the role of transport accessibility and remoteness is analysed. Third, the links between socioeconomic peripheralisation and population development are explored. The results indicate basic structural similarities in the development of peripherality in Czechia and Hungary; however, the Hungarian case corresponds much more than the Czech case to the concept of peripheralisation defined as interrelated processes of economic problems, the accumulation of poverty and social exclusion, and population shrinkage that especially affect remote rural localities. The authors conclude by discussing the role of historically shaped settlement structures, current population compositions, and overall development at the country level.

\footnotetext{
* The article is output of the research projects 'Social disadvantage in rural peripheries in Czechia and in eastern Germany: opportunity structures and individual agency in a comparative perspective' funded by the Czech Science Foundation (No. GA18-05704J) and 'Governing urban marginality in shrinking cities' funded by the Hungarian National Research, Development and Innovation Office (K 119465), and the joint research project 'Spatial polarization (peripherisation), territorial governance and social consequences' of the Institute for Regional Studies at the Centre for Economic and Regional Studies of the Hungarian Academy of Sciences and the Czech Sociology Institute of the Czech Academy of Sciences.
}

Regional Statistics, Vol. 8. No. 2. 2018: 19-45; DOI: 10.15196/RS080204 


\section{Introduction}

Increasing spatial inequalities following the regime change have led an enhanced focus on peripheries in Central and Eastern Europe. Regional peripheralisation can be understood in terms of the cumulative processes of economic decline, deteriorating living conditions, the concentration of social problems and demographic shrinkage, accompanied by a loss of political capabilities and stigmatisation (Kühn 2015, Steinführer et al. 2016). These processes operate at different spatial scales (Šimon 2017), affecting not only large regions (Gorzelak et al. 1995), but also contributing to socioeconomic polarisation between small spatial units. In many cases, peripheralisation processes particularly affect rural areas (Turnock 1996).

The debate on peripheralisation and its social consequences has been especially stimulated by German geography and sociology describing the problems eastern Germany has faced since the 1990s. The former East Germany's transformation resulted in a long-term high unemployment rate, poverty, and social exclusion, as well as a strong out-migration to the western part of the newly unified state. This age-selective migration has led to a significant imbalance in the social structure and accelerated population ageing. Specifically, younger, more educated people has left the eastern part of the country, with more women leaving than men (Leibert 2016). Rural areas were particularly affected by the combination of socioeconomic disadvantage and demographic shrinkage; collectively, these processes have created a downward spiral of decline. Similar tendencies have been recognised in other postsocialist Central European countries too; however, the dynamics and outcomes of peripheralisation markedly differ across countries and regions (Banski 2005, BihariKovács 2005, Musil-Müller 2008, Pénzes 2013a).

Despite the attention devoted to this issue, there is a lack of truly comparative studies to assess the similarities and differences of peripheralisation in individual countries. Such comparative studies could not only investigate whether the sociospatial manifestations of peripheralisation can be generalised, but also identify the limits of such generalisations. In this study, we comparatively analyse the spatial patterns of socioeconomic disadvantage and population dynamics in two Central European countries: Czechia and Hungary. We also aim to examine comparatively two basic elements of the peripheralisation thesis as formulated in the German milieu. First, we analyse the extent to which such social problems as unemployment and poverty are concentrated in economically lagging rural areas. Second, we explore whether peripheralisation's socioeconomic outcomes are indeed accompanied by a population decrease, thus creating a vicious circle of decline. We also detail the relationship between disadvantage on one side and settlement structure and transport accessibility on the other. We demonstrate that the situations in Czechia and Hungary differ despite basic structural similarities, and we discuss the causes of these differences.

Regional Statistics, Vol. 8. No. 2. 2018: 19-45; DOI: 10.15196/RS080204 
The article is structured as follows. First, we briefly review the research on peripheralisation in Central Europe. We define the territory of Central Europe to include the Visegrád countries - Czechia, Slovakia, Poland, and Hungary - and the former East Germany. These countries have all experienced the post-socialist transition, in terms of an interrelation of delayed post-industrial transformations with a specific, post-totalitarian political change (Hampl 2007). Second, we investigate and compare the spatial patterns of poverty and social exclusion indicators on the one hand, and economically lagging rural areas in Czechia and Hungary on the other. Third, we analyse peripherality through the perspectives of settlement structure, transport accessibility and demographic change. The article concludes by discussing the similarities and differences in patterns of social disadvantage and peripherality.

\section{Peripheralisation in Central Europe}

Research on peripheries and the peripheralisation process reveals an ambiguity of definitions, hindering the comparability of research results across countries. These differences stem not only from the conceptualisation of peripherality, but also from the spatial scale on which peripheries are explored. Generally, peripheries' emergence and persistence are part of a more general spatial polarisation process. A comparison can be drawn between successful and growing metropolitan areas as development cores, and peripheries in terms of declining regions in a dependent position, or with deteriorating economic and social conditions. Scientific studies place different emphases on the individual facets of this process, thus using different approaches to delimit peripheries. They either emphasise the geometric aspect of peripherality as it relates to poor accessibility (Novotný et al. 2015), or its relational nature. Peripheries are too loosely related to centres providing jobs (SýkoraMulíček 2009), or largely depend on them and face potential discrimination from the centre (Nolte 1991). Other contributions highlight the challenging economic situation and potential for economic development (Leibert 2013), or peripheries' social conditions and exclusionary effects on the population (Bihari-Kovács 2005, Musil-Müller 2008).

Recently, an academic debate has emerged regarding the dynamic aspects of the peripheralisation process, predominantly in German geography and sociology (Barlösius-Neu 2008, Keim 2006, Kühn 2015, Leibert-Golinski 2016). This approach strongly reflects on the former East Germany's territorial transformation, which had resulted in job loss, unemployment, and out-migration to western Germany. Rural areas were more severely affected by peripheralisation than cities (Steinführer et al. 2016). Against this empirical background, peripheralisation has been repeatedly conceptualised as a complex process, consisting of mutually reinforcing economic, social, and demographic factors resulting in a territory's decline (Keim 2006). All three factors are essential in the peripheralisation process, but simultaneously rein-

Regional Statistics, Vol. 8. No. 2. 2018: 19-45; DOI: 10.15196/RS080204 
force each other. The decoupling of regions from the prevalent economic dynamics of prosperous urban agglomerations results in constrained labour markets in rural areas. Thus, challenges include the access to employment and limited employment choices particularly in rural regions. A vulnerable labour market is accompanied by unemployment, poverty, and social deprivation, contributing to local communities' deterioration. Out-migration and decreasing population can further reduce regions' economic potential and human capital, and can complicate the provision of public and private infrastructure and services. Consequently, a vicious circle of regional decline emerges to further consolidate the peripheries' structural deficits (BarlösiusNeu 2008) and downgrade one region relative to others (Kühn 2015). Although conceptualising the cumulative processes of regional decline theoretically relies on classical polarisation theories (Myrdal 1957), it also more strongly emphasises the quality of living conditions, wealth, demographics, and political interdependencies. Similar complex, vicious circles of regional decline have also been proposed in Czechia and Hungary to explain peripheralisation and the reproduction of coreperiphery relations (Bihari-Kovács 2005, Musil-Müller 2008, Nagy et al. 2015b, Ouředníček et al. 2011, Pósfai-Nagy 2017, Virág 2006).

Many studies have mapped the spatial patterns of peripheries in individual countries (Musil-Müller 2008, Pénzes 2013a) and described not only the economic problems of peripheries (Leibert 2013), but also peripheral regions' demographic dynamics (Leibert 2016), social conditions and problems (Bernard et al. 2016). Aside from these general challenges, numerous studies have focused on the specific problems of peripherality associated with employment and commuting (Alpek et al. 2016, Hardi 2015, Pálóczi 2016, Pénzes 2013b) as well as with consumption and services (Nagy et al. 2015a), or on the role of borders (Hardi 2015). In Czechia, Musil and Müller (2008) coined the term 'inner periphery' to describe areas with the worst social conditions and living standards, located predominantly on regional borders. Novák and Netrdová (2011) later found a similar spatial pattern of areas in decline. Further, Bernard and Šimon (2017) differentiated multiple types of peripheral areas in Czechia, arguing that previous studies had failed to distinguish between different forms of disadvantage in peripheries.

Several Hungarian papers have focused on the differentiation between forms of peripheralisation. A series of studies edited by Kanalas and Kiss (2006) defined several forms of core-periphery relations, such as geographical, economic, or social aspects and power relations. These investigations distinguished between different types of inner peripheries and other peripheral areas located along Hungary's border. Nemes Nagy's (1996) earlier works presented similar results in an examination of core-periphery relations after 1990.

Only a few of these studies were comparative in nature, and works by Pénzes (2013a), Egri and Tánczos (2015), or Novotný et al. (2015) on Central Europe’s

Regional Statistics, Vol. 8. No. 2. 2018: 19-45; DOI: 10.15196/RS080204 
peripheral areas are particularly remarkable. Pénzes (2013a) demonstrated that Central European countries' regional transformations exhibit several common aspects. One of these involves the strengthening of capital cities' economic dominance, the converse of which has been the economic downturn in various regions. On the one hand, negative peripheralisation processes have been recorded in regions affected by structural economic problems and in strongly industrialised regions in particular. On the other hand, traditionally economically weak territories (especially remote rural areas) have further weakened. The ongoing weakening of these traditionally rural regions indicates the formation of a new type of regional disadvantage - in which economic and social marginalisation simultaneously occur - called either 'disconnected rural areas' (Lennert 2017) or 'regional ghettos' (Virág 2006) in Hungary.

Unexpectedly, the German debate on mutually reinforcing economic, social, and demographic peripheralisation processes has been only sparsely reflected in empirical research on peripheries in other post-communist Central European countries, with the exception of Bernard and Šimon (2017). Despite the theoretical formulation of vicious circles of cumulative regional disadvantage, empirical studies have failed to address whether the assumption of mutually reinforcing economic, social, and demographic factors holds true, resulting in the formation of peripheries affected by economic marginalisation restricted labour markets, unemployment, and poverty, and accelerated demographic changes. Evidence even exists that these processes can, in fact, be decoupled from each other. Bernard and Šimon (2017) demonstrated that Czechia has four different types of disadvantaged rural areas: 1. rural peripheries characterised by low qualifications, lower living standards, and the absence of a middle class; 2 . peripheries with an increased risk of social exclusion; 3. peripheries with poor accessibility; and 4. peripheries facing demographic challenges. These four types of peripheries overlap rather weakly.

\section{Data and methods}

\section{Logic and flow of analyses}

Peripheralisation includes three interrelated aspects as highlighted in this paper's theory: social exclusion, manifesting as increased poverty or social vulnerability; certain areas' general economic weakness, mostly related to labour market conditions; and decreased populations, resulting in an unbalanced population structure. First, we use the same set of indicators for both Hungary and Czechia to map the spatial patterns of areas facing problematic, constrained labour markets with low economic opportunities, and areas distinguished by increased unemployment, poverty, and social exclusion. Secondly, we investigate the extent to which these two types of disadvantaged areas overlap, and we examine these areas' population dynamics. The analysis was conducted on a detailed spatial level using LAU 2 units:

Regional Statistics, Vol. 8. No. 2. 2018: 19-45; DOI: 10.15196/RS080204 
6,251 in Czechia and 3,154 in Hungary. As peripheralisation processes operate at different spatial levels, they affect different-sized regions. Using small units enabled us to reveal the resulting spatial patterns of peripheralisation outcomes, including the clustering of peripheral areas within larger regions.

Analysing the socioeconomic manifestations of peripheralisation implies several considerations that must be taken into account when choosing tools to investigate and interpret evidence. One consideration is that social systems' dysfunctions - as generators of processes leading to the exclusion of certain social groups from their relationships with society - are often marked by a clear spatial manifestation (Madanipour et al. 2015, Nagy et al. 2015b). Another consideration is that while these manifestations illustrate peripheralisation's different dimensions, they are also multidimensional, which implies that multiple indices should be chosen to explore the characteristics of peripheralisation. Thus, a principal component analysis (PCA) was used as a dimensionality reduction tool and translated the studied phenomenon's multidimensional features into single measures, which were easier to compare and interpret. The PCA is commonly used in research on area-level disadvantage and deprivation to create composite indices that can be included in statistical models (Kearns et al. 2000, Koós 2015, Messer et al. 2006).

The comparison of the PCA model's results between the two countries was further advanced by considering how the investigated aspects of peripheralisation relate to different spatio-structural characteristics. As a part of this analysis, we investigate the interrelations between the types of disadvantages represented by different components and the settlement structure, transport accessibility, and population development in each country. We anticipate not only that the spatial distribution of social exclusion and labour market constraints would exhibit regional specificities, but also that a position in the settlement structure might characterise how peripheralisation affects different territorial units. Therefore, the PCA's results are examined using a cross-section of municipalities' population size categories. Further, the distance from/access to more central parts of the settlement structure might shape spatial patterns of social exclusion and the labour market. As services and opportunities are selectively concentrated in urban centres, these are more available to - and accessible by - populations living in proximal areas. Thus, living in poorly accessible areas might lead to socioeconomic disadvantages due to the higher costs related to transport or the restricted access to urban services and opportunities. The lack of access to centres could enhance socioeconomic disadvantages and lead to peripheralisation, while accessibility patterns themselves could be regarded as indices of peripheries. This paper analyses Czech and Hungarian municipalities' accessibility to urban centres of different sizes (5,000-10,000-20,000 inhabitants) in a crosscomparison with the PCA's results. These results are further compared with selected demographic indicators to reflect the demographic challenges related to periph-

Regional Statistics, Vol. 8. No. 2. 2018: 19-45; DOI: 10.15196/RS080204 
eralisation. This part of the analysis provides an insight into population development in areas affected by the socioeconomic aspects of peripheralisation.

\section{Data description}

The analysis involves socioeconomic indicators, those related to the settlement structure and demographic indicators (see Table 1). The data were selected at the municipality level (LAU 2$)$ in both Czechia $(n=6,251)$ and Hungary $(n=3,154)$ by using 2011 as the reference year. The period between 2001 and 2011 was used in the case of dynamic variables. The primary sources for data collection included Czech and Hungarian census databases, as these datasets provide the widest range of socioeconomic variables and represent each country's entire population at a low administrative level. The income measures incorporated data from other sources: the Czech Ministry of Finance and the Hungarian National Tax and Customs Administration database.

\section{Variables related to the socioeconomic aspects of peripheralisation}

A pool of potential indicators of peripheralisation was collected to cover two dimensions of disadvantage. The first reflects the aspects of constrained labour markets, with little innovation, poor income opportunities, low-skilled jobs, and aboveaverage agricultural employment. The second reflects the aspects of poverty and social exclusion among marginalised population groups, including unemployment, early school leaving, poor education, and low-quality housing. We explicitly limited the number of indicators to cover some basic aspects of the concepts under study. ${ }^{1}$

\section{Indicators of settlement structure and transport accessibility}

Patterns of socioeconomic disadvantage are influenced by their position within the settlement structure. Two types of such measures were considered: 1 . the municipality's size; and 2. its accessibility to the nearest urban centre. Municipality size categories are represented using the number of inhabitants, with thresholds of 200-500-2,000-10,000-100,000 inhabitants and the capital city. Instead of the settlements' legal status, municipality size was selected to ensure comparability, as no legal difference exists between villages and towns in Czechia, and their role and function in the settlement structure predominantly depend on their size.

Transport accessibility to the nearest urban centre refers to the difficulties in accessing services and (employment) opportunities as a result of the growing distance

\footnotetext{
${ }^{1}$ This approach is explicitly deductive. A limited number of indicators were selected to express important aspects of previously defined theoretical concepts, similar to the process of developing various area-level deprivation indices (e.g. Kearns et al. 2000, Messer et al. 2006). Approaches based on including a broader range of indicators (e.g. Novák-Netrdová 2011) proceed inductively, aiming to investigate existing socio-spatial patterns in an explorative way. A deductive, theory-driven approach seems more reasonable for our analysis, in which the peripheralisation theory represents a theoretical point of departure.
}

Regional Statistics, Vol. 8. No. 2. 2018: 19-45; DOI: 10.15196/RS080204 
from towns and cities. The multiplicity of services and infrastructure that people commonly access - such as jobs, healthcare, education, and shopping - was operationalised to a simple model based on the accessibility of cities of three different sizes, allowing for direct, cross-national comparisons. Towns and cities with population sizes of $5,000+, 10,000+$ and $20,000+$ were selected as centres of accessibility for services (Hungary: $n_{5,000}=278, n_{10,000}=142, n_{20,000}=61$; Czechia: $n_{5,000}=256$, $\left.n_{10,000}=130, n_{20,000}=62\right)$. Further, every service has a catchment area that depends on a minimum number of users required for a service to be run both effectively and in an economical manner. Three different sizes were selected as approximations of differences in particular services' catchment areas. We opted for a lower-level urban hierarchy, as smaller cities contain most of the basic everyday services used by the population in everyday life. This decision was further supported by the fact that most of the travel for services occurs over short distances, or typically within a 15-minute drive. The accessibility model is based on the actual road network, and it measures the travel distance ${ }^{2}$ from every municipality to each site's closest centre of accessibility. The method for shortest path accessibility measurement reflects the rational decision to visit the closest service available. ${ }^{3}$ The index of accessibility measures how many kilometres one must travel from a municipality to reach the closest urban centres for three defined sizes in every Czech and Hungarian municipality.

\section{Demographic indicators}

The goals of this study involve investigating how socioeconomic disadvantage and peripheralisation processes relate to population dynamics as well as the resulting population structure imbalances in Czechia and Hungary. Several demographic indicators were selected to answer this question and were analysed in a cross-section of socioeconomic disadvantage as caused by peripheralisation: age structure, gender balance, and the components of population change.

\footnotetext{
${ }^{2}$ Measurements could be improved by replacing travel distance indices with travel time indices; however, we did not have comparable datasets for both countries to allow for such an analysis. The analysis using travel distance indices is sufficiently robust to answer this study's research questions.

3 As the accessibility model was computed only for urban centres within a country, it was not sensitive to possible centres of accessibility beyond a country's boundaries. Although the model only approximates reality, we are convinced that it is robust enough to capture the basic differences between municipalities with good, average and poor accessibility. The model's key added value is that it applies the same data and identical variables to delimit spatial accessibility in both Hungary and Czechia. Further, the grouping of three different centre sizes in Hungary and in Czechia is similar, thus supporting the results' comparability.
}

Regional Statistics, Vol. 8. No. 2. 2018: 19-45; DOI: 10.15196/RS080204 
Two faces of peripherality: labour markets, poverty, and population dynamics in Hungary and Czechia

Table 1

\section{Indicators used in the comparative analysis of peripheralisation} in Czechia and Hungary

\begin{tabular}{c|c|c|c}
\hline Indicator & Measure & Source & $\begin{array}{c}\text { Year/ } \\
\text { Period }\end{array}$ \\
\hline
\end{tabular}

A) Variables related to constrained labour markets

Share of the employed in occupations (ISCO 1-2), aged 25-50

\begin{tabular}{|l|l|l|l|l} 
Per cent & $\begin{array}{l}\text { Czech Statistical Office (ČSU)/ } \\
\text { Hungarian Central Statistical } \\
\text { Office (HCSO) census data- } \\
\text { base } \\
\text { ČSU/HCSO census database }\end{array}$ \\
Per cent & $\begin{array}{l}\text { ČSU/HCSO census database } \\
\text { CZK/HUF } \\
\text { Czech Ministry of Finance/ } \\
\text { Hungarian National Tax and } \\
\text { Customs Administration data- } \\
\text { base }\end{array}$
\end{tabular}

Average monthly income from employment

$$
\begin{aligned}
& \text { Customs Administration data- } \\
& \text { base }
\end{aligned}
$$

B) Variables related to poverty and social exclusion
Share of occupied dwellings without comfort

\begin{tabular}{|l|l|} 
Per cent & ČSU $/$ HCSO census database \\
Per cent & ČSU $/$ HCSO census database \\
Per cent & ČSU $/$ HCSO census database
\end{tabular}

C) Variables related to the settlement structure

\begin{tabular}{l|l|l|l} 
Municipality size categories by population & Inhabitants & ČSU/HCSO census database & 2011 \\
Accessibility to the nearest urban centres & Kilometres & Country road network & 2011
\end{tabular} 


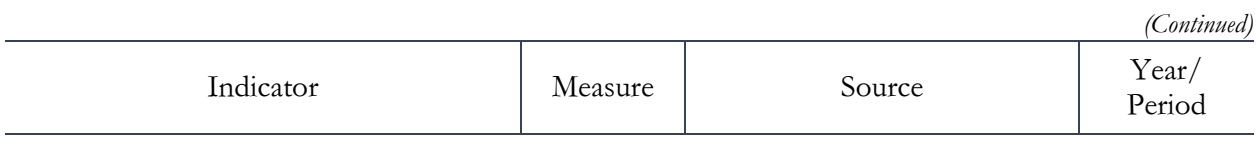

D) Demographic variables

Share of inhabitants aged $65+$

\begin{tabular}{|c|c|c|}
\hline Per cent & ČSU/HCSO census database & 2011 \\
\hline Per cent & ČSU/HCSO census database & 2011 \\
\hline Per cent & ČSU/HCSO census database & 2011 \\
\hline Per cent & $\begin{array}{l}\text { ČSU demography database/ } \\
\text { HCSO census database }\end{array}$ & 2001-2011 \\
\hline $\begin{array}{l}1,000 \text { inhab- } \\
\text { itants }\end{array}$ & $\begin{array}{l}\text { ČSU demography database/ } \\
\text { HCSO census database }\end{array}$ & 2001-2011 \\
\hline $\begin{array}{l}1,000 \text { inhab- } \\
\text { itants }\end{array}$ & $\begin{array}{l}\text { ČSU demography database/ } \\
\text { HCSO census database }\end{array}$ & 2001-2011 \\
\hline
\end{tabular}

a) Over-qualification is traditionally measured as the years of education required for a job and the years spent in education (Brynin-Longhi 2009). Our case measured the educational degree obtained and compared it to the educational degree required, or that held by most employees with the same occupation. Given the rough categorisation of occupations using the ISCO's one-digit classification, the indicator should be understood as an approximation.

b) Early leaver from education and training refers to a person aged 18 to 24 who has completed, at most, an ISCED-2 educational level, and who is not involved in further education or training. See https://ec.europa.eu/eurostat/statistics-explained/index.php?title=Glossary:Early_leaver_from_education_and_training

Note. ISCED - International Standard Classification of Education; ISCO - International Standard Classification of Occupations; NACE - Statistical Classification of Economic Activities in the European Community.

The use of census data in the analysis partially guarantees the Czech and Hungarian cases' comparability. Regarding the European Union's 2011 population and housing censuses, European legislation has defined a high level of harmonisation regarding variables and data to be collected (Eurostat 2011). The Czech and Hungarian data's comparability has further improved by using international standards in the classifications related to economic activities (NACE Rev. 2), occupations (ISCO-08), and qualifications (ISCED 2011). Harmonisation issues have primarily affected housing and income data. Czech and Hungarian data related to low-comfort housing refers to slightly different types of housing standards. As these are complex measures, different combinations of vulnerabilities related to the availability of different types of housing amenities can be regarded as meaningful in each case. Therefore, the two countries' national standards are considered in denoting the two countries' housing disadvantages. The indicator of income from employment is suitable only for an indirect comparison, such as comparing the two countries' inequalities. In Hungary's case, this indicator was calculated by dividing the gross taxable income from employment by the number of income tax-payers, which refers to a wider population pool, in the absence of published data on the direct number of taxpayers based on income from employment. Regarding the Czech income data, the data provided by the Ministry of Finance have only covered employees who

Regional Statistics, Vol. 8. No. 2. 2018: 19-45; DOI: 10.15196/RS080204 
processed their tax returns by themselves (approximately one-third of the employed population).

\section{Analysis}

\section{Indices of disadvantage}

The first set of variables (see Table 1, Part A) was used to produce an index characterised by high values in areas affected by constrained labour market conditions, with limited economic opportunities for the local population. The poverty and social exclusion index is based on the second set of variables (see Table 1, Part B). Both sets of variables correlate fairly well internally in both countries, although the correlations are generally higher in the Hungarian case; consequently, this indicates a stronger spatial overlap of different aspects of disadvantage in Hungary than in Czechia. The first principal component obtained by the PCA for each variable set was retained for further analyses. This component represents the unique linear combination accounting for the largest possible variation proportion of the underlying variables. ${ }^{4}$ Tables 2 and 3 present the results of the PCAs of both datasets for both countries. ${ }^{5}$

Table 2

PCA results - Constrained labour markets, 2011

\begin{tabular}{l|r|r}
\hline \multirow{2}{*}{ PCA result } & \multicolumn{2}{c}{ First component loading } \\
\cline { 2 - 3 } & Czechia & Hungary \\
\hline Share of the employed in occupations ISCO 1-2, aged 25-50 & -0.84 & -0.88 \\
Share of overqualified, employed inhabitants & 0.68 & 0.46 \\
Share of the economically active employed in agriculture & 0.57 & 0.61 \\
Average monthly income from employment & -0.69 & -0.82 \\
Total variance explained (\%) & 49.10 & 51.00
\end{tabular}

\footnotetext{
4 This study's deductive nature has led to separate analyses of the sets of variables, and in using the first principle component, which represents a major part of the underlying indicators' variation. A factor rotation would be more reasonable in an exploratory use of the factor analysis.

${ }^{5}$ We have controlled the resulting indices' robustness by comparing them to alternative composite scores, created by summing the underlying variables' normalised values. An extremely high correlation was found $(r=0.994$ and 0.997 in the Czech case; $r=0.990$ and 0.999 in the Hungarian case), indicating the indices' strong consistency.
}

Regional Statistics, Vol. 8. No. 2. 2018: 19-45; DOI: 10.15196/RS080204 
PCA results - Poverty and social exclusion, 2011

\begin{tabular}{l|c|c}
\hline \multirow{2}{*}{\multicolumn{1}{c|}{ PCA result }} & \multicolumn{2}{c}{ First component loading } \\
\cline { 2 - 3 } & Czechia & Hungary \\
\hline Unemployment rate & 0.74 & 0.81 \\
Early school leavers & 0.70 & 0.87 \\
Share of inhabitants aged 25-50 with elementary education & 0.79 & 0.92 \\
Share of occupied dwellings without comfort & 0.50 & 0.79 \\
Total variance explained (\%) & 47.60 & 71.20
\end{tabular}

Hungary's larger explained variance in the poverty and social exclusion index than in Czechia is an outcome of the latter's less inter-correlated variables, indicating fewer overlapping spatial patterns of different poverty and exclusion symptoms than in Hungary. Poor-quality housing, represented by the 'share of dwellings without comfort', is particularly weakly related to the other measures of disadvantages in Czechia. The resulting component scores were saved and used as index values in all subsequent analyses. Maps for both countries (see Figures 1 to 4) present the spatial distribution of both composite indices.

Tables 4 and 5 illustrate the mean values of the underlying indicators in areas represented by the highest, average, and lowest terciles of both composite indices. The results document remarkable differences between both countries' well and poorly performing areas. On average, approximately half share of people with highly qualified occupations live in poorly performing areas in terms of labour market constraints, compared to well-performing areas. Nearly twice as many residents experience over-qualification - or have higher education than normally necessary for their job - in low-performing areas. More than three times more people are employed in agriculture, and the average gross wages are approximately one-third lower than wages in well-performing areas. Despite the overall slightly worse situation in Hungary, the intra-country differences are remarkably similar for both countries; territorial differences in poverty and social exclusion are more pronounced. The unemployment rate in poorly performing areas is approximately twice as high as in well-performing areas, with four times more youth leaving school early, and three times more middle-aged residents with only an elementary education. Moreover, Hungary's poorly performing areas in terms of high poverty and social exclusion have more low-quality housing.

Regional Statistics, Vol. 8. No. 2. 2018: 19-45; DOI: 10.15196/RS080204 
Two faces of peripherality: labour markets, poverty, and population dynamics in Hungary and Czechia

Figure 1

Index of disadvantage - Constrained labour market in Hungary, 2011

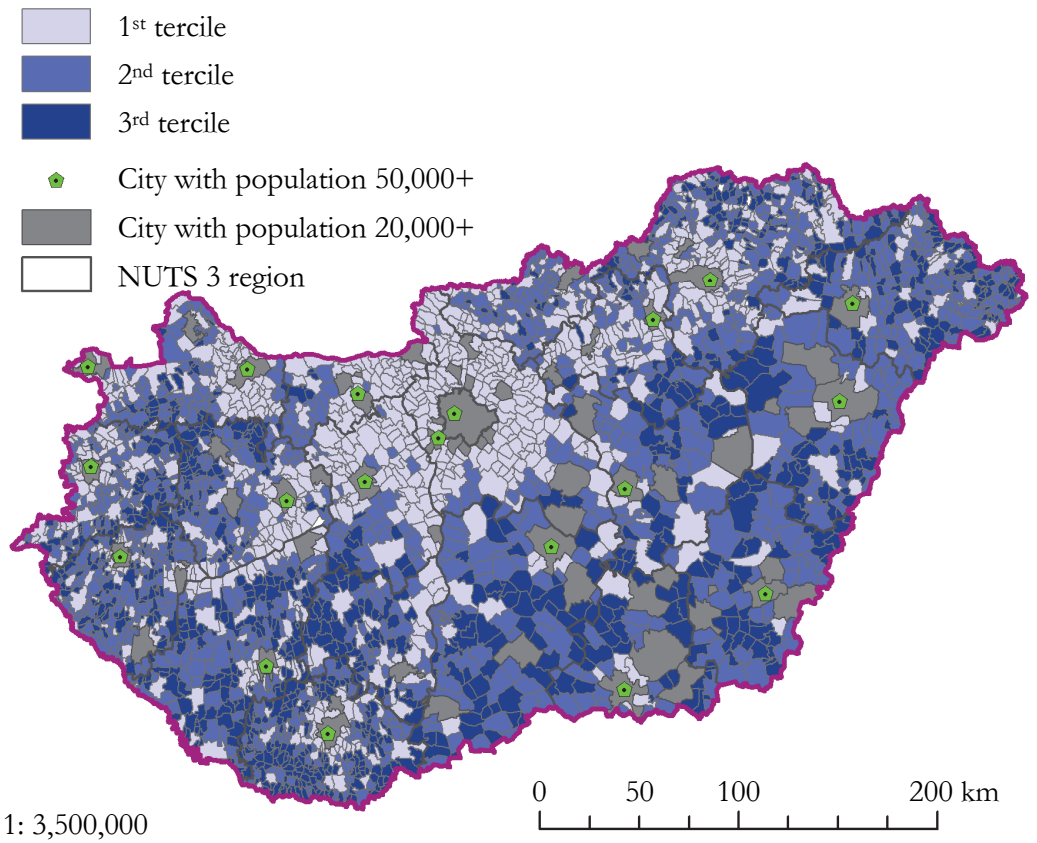

Figure 2

Index of disadvantage - Constrained labour market in Czechia, 2011

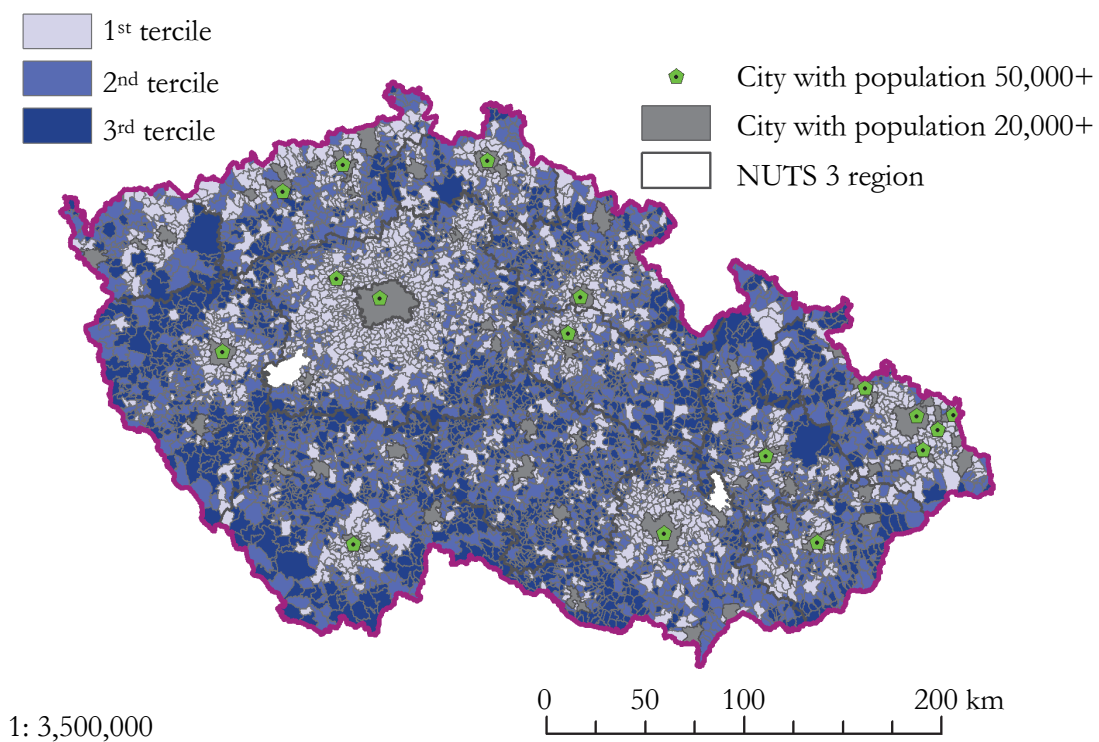

Regional Statistics, Vol. 8. No. 2. 2018: 19-45; DOI: 10.15196/RS080204 
Figure 3

Index of disadvantage - Poverty and social exclusion in Hungary, 2011

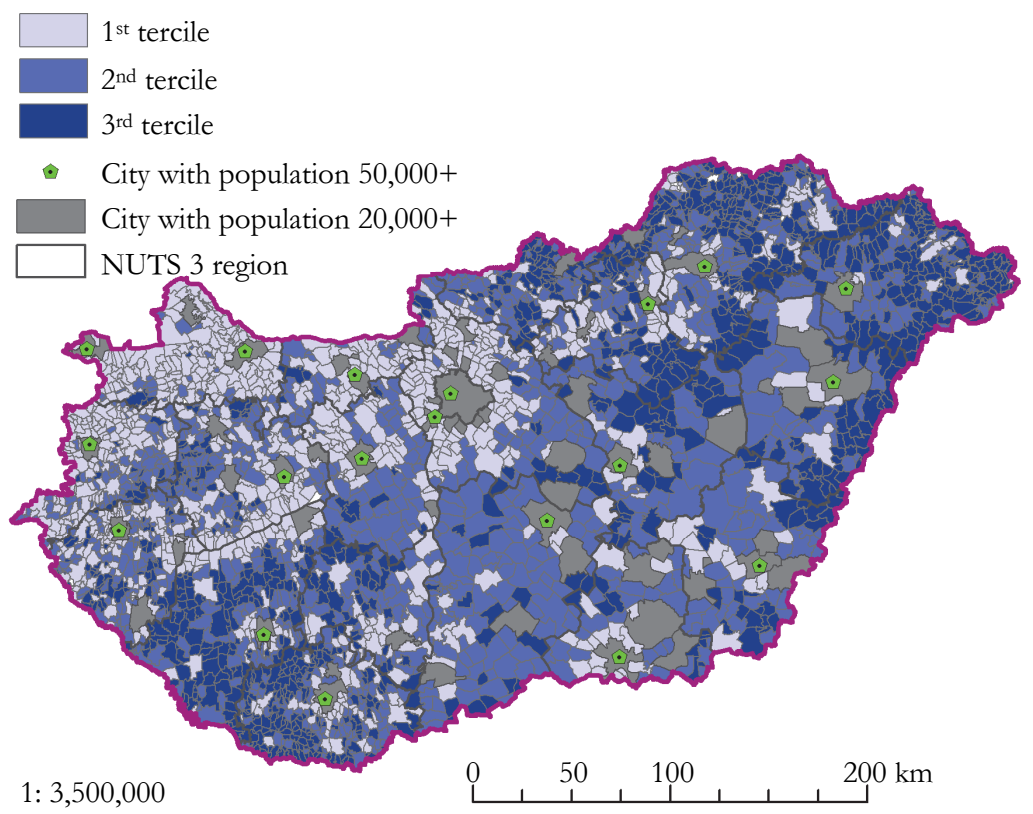

Figure 4

Index of disadvantage - Poverty and social exclusion in Czechia, 2011

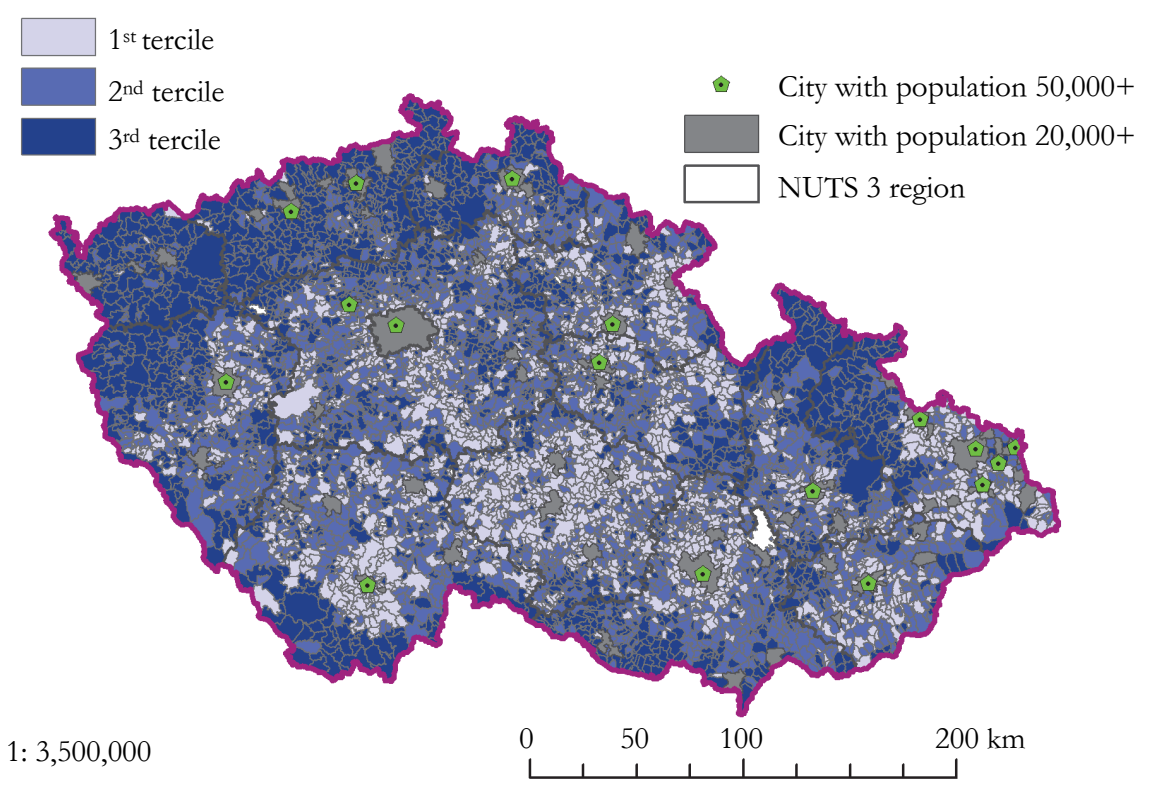

Regional Statistics, Vol. 8. No. 2. 2018: 19-45; DOI: 10.15196/RS080204 
Two faces of peripherality: labour markets, poverty, and population dynamics in Hungary and Czechia

Table 4

Mean values of underlying variables in different areas according to the terciles of the composite index 'constrained labour markets', 2011

\begin{tabular}{c|c|c|c|c}
\hline $\begin{array}{c}\text { Area according to the } \\
\text { 'constrained labour } \\
\text { markets' composite } \\
\text { index }\end{array}$ & $\begin{array}{c}\text { Share of the em- } \\
\text { ployed in occupa- } \\
\text { tions ISCO 1-2, } \\
\text { aged 25-50, \% }\end{array}$ & $\begin{array}{c}\text { Share of overquali- } \\
\text { fied employed } \\
\text { inhabitants in } \\
\text { population, } \%\end{array}$ & $\begin{array}{c}\text { Share of the eco- } \\
\text { nomically active } \\
\text { employed in agri- } \\
\text { culture, } \%\end{array}$ & $\begin{array}{c}\text { Average monthly } \\
\text { gross wage, EUR }\end{array}$ \\
\hline
\end{tabular}

Czechia

\begin{tabular}{l|r|r|r|r} 
Well-performing & 23.6 & 15.5 & 4.6 & $1,146.40$ \\
Average & 16.1 & 20.7 & 8.1 & 860.50 \\
Poorly performing & 11.0 & 27.3 & 14.4 & 756.60 \\
& & Hungary & & 472.20 \\
Well-performing & 18.6 & 24.1 & 4.8 & 373.40 \\
Average & 11.1 & 28.0 & 9.4 & 302.20
\end{tabular}

Table 5

Mean values of underlying variables in different areas according to the terciles of the composite index 'poverty and social exclusion', 2011

\begin{tabular}{c|c|c|c|c}
\hline $\begin{array}{c}\text { Area according to the } \\
\text { poverty and social } \\
\text { exclusion' composite } \\
\text { index }\end{array}$ & $\begin{array}{c}\text { Unemployment } \\
\text { rate, \% }\end{array}$ & $\begin{array}{c}\text { Share of early } \\
\text { school-leavers in } \\
\text { population, } \%\end{array}$ & $\begin{array}{c}\text { Share of inhabitants } \\
\text { aged 25-50 with } \\
\text { elementary educa- } \\
\text { tion in population, } \\
\%\end{array}$ & $\begin{array}{c}\text { Share of occupied } \\
\text { dwellings without } \\
\text { comfort, } \%\end{array}$ \\
\hline
\end{tabular}

Czechia

\begin{tabular}{|c|c|c|c|c|}
\hline Low exclusion & 7.1 & 2.6 & 4.1 & 4.7 \\
\hline Average exclusion & 9.9 & 5.5 & 6.4 & 6.4 \\
\hline High exclusion & 14.3 & 12.3 & 12.5 & 8.6 \\
\hline \multicolumn{5}{|c|}{ Hungary } \\
\hline Low exclusion & 9.6 & 8.2 & 13.1 & 6.1 \\
\hline Average exclusion & 14.4 & 16.3 & 24.1 & 12.9 \\
\hline High exclusion & 24.5 & 34.9 & 42.2 & 24.0 \\
\hline
\end{tabular}

Regional Statistics, Vol. 8. No. 2. 2018: 19-45; DOI: 10.15196/RS080204 


\section{Indices of disadvantage within the settlement structure}

The mean component scores by population size indicate remarkable systematic differences (see Table 6). The constrained labour market indicator in both countries documents a clear, expected pattern, with the settlements' size positively related to the labour market situation. Specifically, the smallest settlements experienced the least favourable labour market situation. In the case of poverty and social exclusion, only Hungary's relationship with population size is pronounced.

Mean component scores by settlement population category, 2011

\begin{tabular}{l|r|r|r|r}
\hline \multirow{2}{*}{ Population category (LAU 2) } & \multicolumn{2}{|c|}{$\begin{array}{c}\text { 'Constrained labour markets' } \\
\text { composite index }\end{array}$} & \multicolumn{2}{c}{$\begin{array}{c}\text { 'Poverty and social exclusion' } \\
\text { composite index }\end{array}$} \\
\cline { 2 - 5 } & Czechia & Hungary & Czechia & Hungary \\
\hline $0-200$ & 0.447 & 0.536 & 0.077 & 0.496 \\
$201-500$ & 0.149 & 0.438 & 0.070 & 0.227 \\
$501-2,000$ & -0.256 & -0.022 & -0.106 & -0.036 \\
$2,001-10,000$ & -0.618 & -0.497 & -0.071 & -0.328 \\
10,001-100,000 & -0.958 & -1.360 & 0.003 & -0.793 \\
100,001+ & -1.751 & -2.236 & -0.107 & -1.066 \\
Capital city (Prague/Budapest) & -2.862 & -3.513 & -0.503 & -1.169
\end{tabular}

Spearman's correlation was computed to statistically assess the relationship between population size and component scores (see Table 7). A statistically significant $(p<0.05)$, negative correlation was found in every case, verifying the importance of municipality size. However, it should be noted that this correlation is always weaker in Czechia than in Hungary, with an especially striking difference in the correlation between municipality size and social exclusion $(-0.0299$ in Czechia and -0.2860 in Hungary). This correlation reflects this relationship's factual insignificance in Czechia, and points to a more socially polarised Hungarian settlement structure. The intercountry differences are smaller in the case of the constrained labour market indicator ( -0.3715 in Czechia and -0.4497 in Hungary).

The correlation matrix also reveals the interplay of the socioeconomic aspects of peripheralisation as well as its country-specific nature. The correlation between the two composite indices was positive in both cases, indicating that the constrained labour market index score increases as the poverty index increases; however, Czechia exhibits a weak correlation between social exclusion and a constrained labour market $(+0.2285)$, indicating that these two aspects of peripheralisation may be spatially separated. In a Czech municipality with constrained labour market conditions, the high probability of poverty and social exclusion cannot be directly predicted, as most rural villages struggling with limited job availability cannot be grouped with areas of increased poverty and unemployment. Thus, peripheralisation's economic and social aspects are spatially decoupled from each other in Czechia.

Regional Statistics, Vol. 8. No. 2. 2018: 19-45; DOI: 10.15196/RS080204 
A stronger spatial overlap of different aspects of peripheralisation can be observed in Hungary, which is reflected in the higher correlation coefficient $(+0.6288)$. Thus, areas in Hungary with increased poverty in many cases are rural villages affected by an underdeveloped labour market. Poor job availability, low economic innovation, and low qualifications closely connect to the spatial patterns of poverty, unemployment, and social exclusion.

Table 7

\section{Relationship between population size and component scores in Czechia and Hungary (Spearman's correlation matrix), 2011}

\begin{tabular}{|c|c|c|c|c|c|c|}
\hline \multirow[b]{3}{*}{ Category/index } & \multicolumn{6}{|c|}{ Category/index } \\
\hline & \multicolumn{3}{|c|}{ Czechia $(n=6,229)$} & \multicolumn{3}{|c|}{ Hungary $(n=3,141)$} \\
\hline & $\begin{array}{c}\text { Population } \\
\text { category }\end{array}$ & $\begin{array}{l}\text { 'Poverty and } \\
\text { social exclu- } \\
\text { sion' com- } \\
\text { posite index }\end{array}$ & $\begin{array}{c}\text { 'Constrained } \\
\text { labour } \\
\text { market' } \\
\text { composite } \\
\text { index }\end{array}$ & $\begin{array}{c}\text { Population } \\
\text { category }\end{array}$ & $\mid \begin{array}{c}\text { 'Poverty and } \\
\text { social exclu- } \\
\text { sion' com- } \\
\text { posite index }\end{array}$ & $\begin{array}{c}\text { 'Constrained } \\
\text { labour } \\
\text { market' } \\
\text { composite } \\
\text { index }\end{array}$ \\
\hline Population category & 1.0000 & & & 1.0000 & & \\
\hline $\begin{array}{l}\text { 'Poverty and social } \\
\text { exclusion' composite } \\
\text { index }\end{array}$ & $-0.0299 *$ & 1.0000 & & $-0.2860 *$ & 1.0000 & \\
\hline $\begin{array}{l}\text { 'Constrained labour } \\
\text { market' composite } \\
\text { index }\end{array}$ & $-0.3715^{*}$ & $0.2285^{*}$ & 1.0000 & $-0.4497 *$ & $0.6288^{*}$ & 1.0000 \\
\hline
\end{tabular}

$* p<0.05$.

\section{Disadvantage indices from the accessibility perspective}

Spatial accessibility measures the access to services and opportunities provided in a limited number of places, such as urban centres. Thus, access to such centres is theoretically unequal by definition, and leads to disadvantage for the populations outside of such centres; however, an evaluation of any possible disadvantage cannot be performed solely using spatial accessibility measures. Various redistributive mechanisms, selective population mobility, and technological developments in contemporary societies can significantly modify spatial accessibility's role in social disadvantage, and thus, can mitigate or even negate poorer spatial accessibility's effects on disadvantage. The actual link between spatial accessibility and disadvantage de facto demonstrates the strength and effectiveness of redistributive and inclusive mechanisms in society, and in preventing exclusion by transport accessibility.

This comparison reveals two important findings. First, the key difference between rural areas in Czechia and Hungary is that in the former they are generally closer to urban centres than in the latter (see Table 8). This difference in the structure of settlement systems shapes the access to the services and infrastructure con-

Regional Statistics, Vol. 8. No. 2. 2018: 19-45; DOI: 10.15196/RS080204 
centrated in cities and towns (see Figures 5 and 6). Thus, prevalent remote rurality can ignite more exclusion due to a lack of access to opportunities. Second, urban centres' accessibility affects the two dimensions of disadvantage more in Hungary than in Czechia. Regarding poverty and social exclusion, a clear link exists between transport accessibility and social exclusion in Hungary $\left(R^{2}=0.208\right)$. In contrast, the link between social exclusion and accessibility is low in Czechia $\left(R^{2}=0.053\right)$, and four times weaker than in Hungary. The disadvantage stemming from constrained rural labour markets relates to transport accessibility in similar ways in both Czechia $\left(R^{2}=0.190\right)$ and Hungary $\left(R^{2}=0.208\right)$. The smallest municipalities in Hungary (0-200 inhabitants) are excluded more often, even when they are relatively close to urban centres. Generally, Hungarian localities' transport accessibility matters regarding citizens' chance to be affected by social or economic disadvantage more than in Czechia; however, this difference is driven far more by the dimensions of social exclusion and poverty than by a constrained rural labour market.

Table 8

Dimensions of disadvantage in the accessibility framework, 2011

\begin{tabular}{|c|c|c|c|c|c|c|c|}
\hline \multirow[b]{2}{*}{$\begin{array}{c}\text { Area } \\
\text { category }\end{array}$} & \multirow[b]{2}{*}{$\begin{array}{c}\text { Index of } \\
\text { accessibility, } \\
\mathrm{km}\end{array}$} & \multicolumn{3}{|c|}{ Czechia } & \multicolumn{3}{|c|}{ Hungary } \\
\hline & & $\begin{array}{c}\text { Share of } \\
\text { the area } \\
\text { category } \\
\text { in the } \\
\text { total area } \\
\text { of the } \\
\text { country, } \\
\%\end{array}$ & $\begin{array}{c}\text { Mean value } \\
\text { of the index } \\
\text { of } \\
\text { disadvantage }\end{array}$ & $\begin{array}{l}\text { Standard } \\
\text { deviation }\end{array}$ & $\begin{array}{c}\text { Share of } \\
\text { the area } \\
\text { category } \\
\text { in the } \\
\text { total area } \\
\text { of the } \\
\text { country, } \\
\%\end{array}$ & $\begin{array}{c}\text { Mean value } \\
\text { of the index } \\
\text { of } \\
\text { disadvantage }\end{array}$ & $\begin{array}{l}\text { Standard } \\
\text { deviation }\end{array}$ \\
\hline \multicolumn{8}{|c|}{ Poverty and social exclusion } \\
\hline Urban areas & 0 & 3.6 & -0.18 & 0.68 & 2.3 & -0.88 & 0.48 \\
\hline $\begin{array}{l}\text { Suburban } \\
\text { areas }\end{array}$ & $1-30$ & 41.5 & -0.15 & 0.86 & 20.8 & -0.52 & 0.64 \\
\hline $\begin{array}{l}\text { Close rural } \\
\text { areas }\end{array}$ & $31-60$ & 45.9 & 0.03 & 0.99 & 41.6 & -0.09 & 0.86 \\
\hline Rural areas & $61-90$ & 8.4 & 0.58 & 1.42 & 28.0 & 0.33 & 0.99 \\
\hline $\begin{array}{l}\text { Remote rural } \\
\text { areas }\end{array}$ & $91+$ & 0.6 & 1.34 & 1.67 & 7.3 & 1.03 & 1.42 \\
\hline \multicolumn{8}{|c|}{ Constrained rural labour markets } \\
\hline Urban areas & 0 & 3.6 & -1.07 & 0.84 & 2.3 & -1.66 & 0.89 \\
\hline $\begin{array}{l}\text { Suburban } \\
\text { areas }\end{array}$ & $1-30$ & 41.5 & -0.35 & 0.99 & 20.8 & -0.67 & 1.03 \\
\hline $\begin{array}{l}\text { Close rural } \\
\text { areas }\end{array}$ & $31-60$ & 45.9 & 0.27 & 0.86 & 41.6 & 0.07 & 0.83 \\
\hline Rural areas & 61-90 & 8.4 & 0.68 & 0.85 & 28.0 & 0.42 & 0.76 \\
\hline $\begin{array}{l}\text { Remote rural } \\
\text { areas }\end{array}$ & $91+$ & 0.6 & 0.75 & 0.73 & 7.3 & 0.42 & 1.11 \\
\hline
\end{tabular}

Regional Statistics, Vol. 8. No. 2. 2018: 19-45; DOI: 10.15196/RS080204 
Two faces of peripherality: labour markets, poverty, and population dynamics in Hungary and Czechia

Spatial accessibility in Hungary, 2011

Figure 5

Index of accessibility (km)

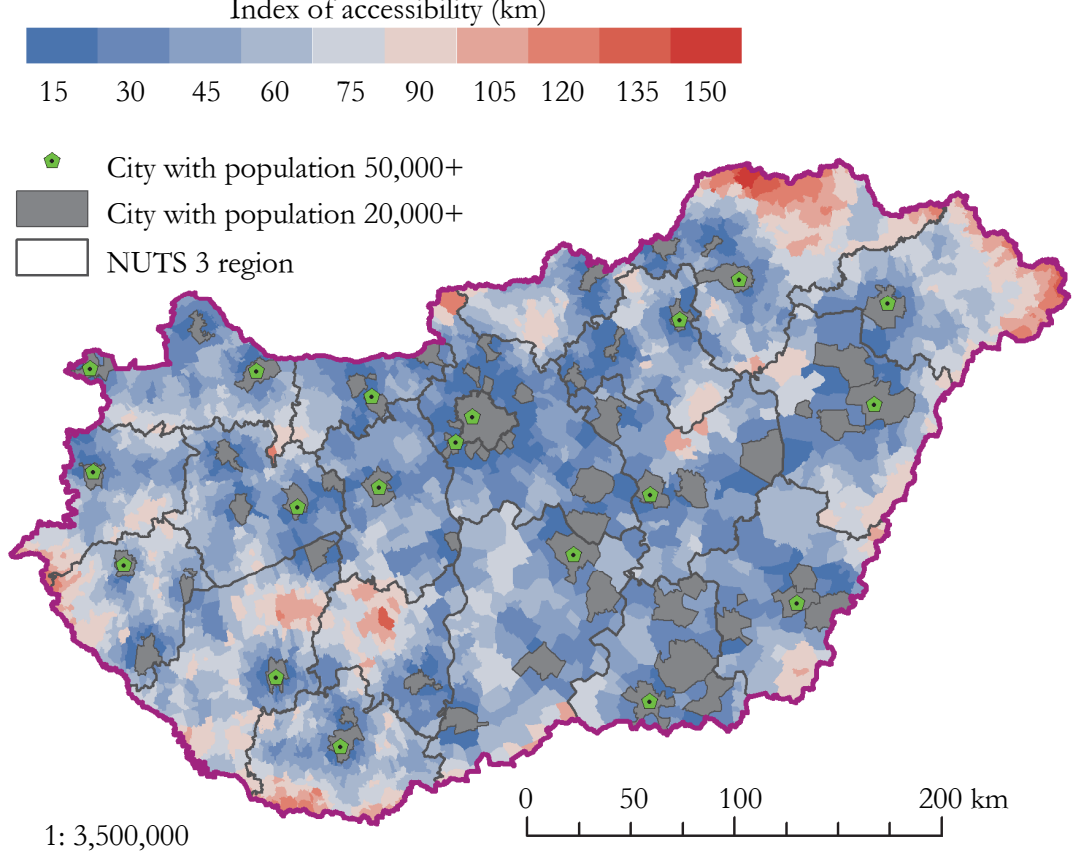

Figure 6

Spatial accessibility in Czechia, 2011

Index of accessibility $(\mathrm{km})$

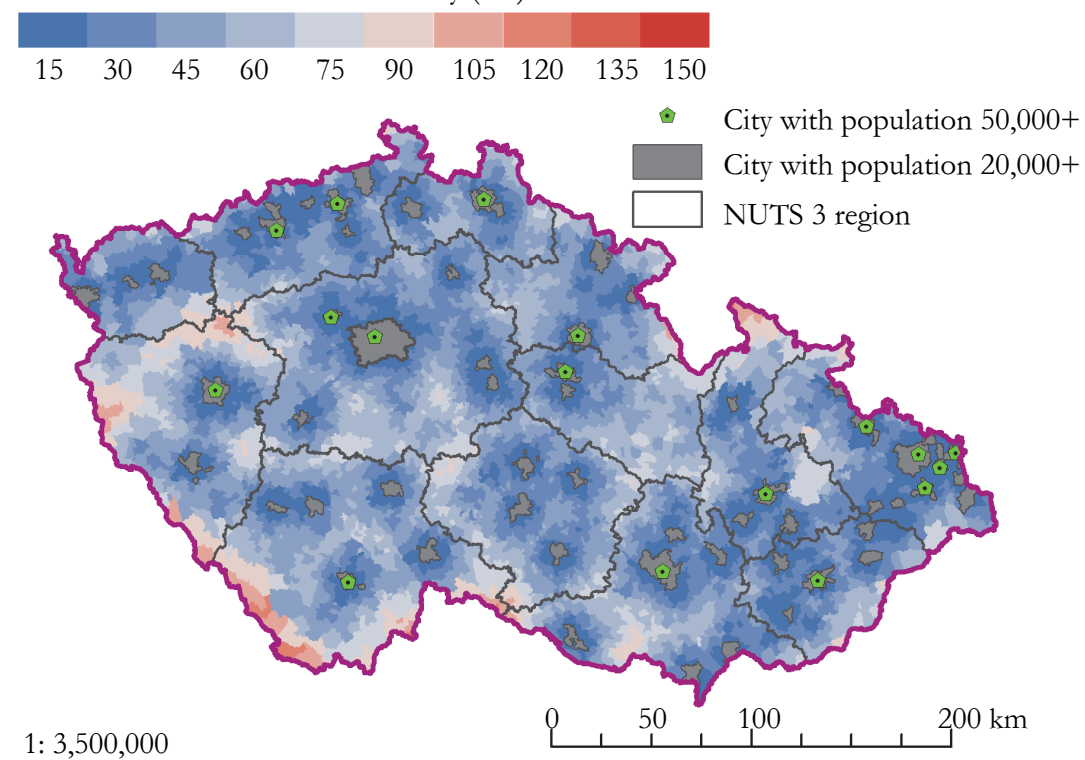

Regional Statistics, Vol. 8. No. 2. 2018: 19-45; DOI: 10.15196/RS080204 


\section{Disadvantage and demographic change}

The investigation of demographic trends provides some insight into how the socioeconomic aspects of peripheralisation are associated with a population's decline. The demographic trends in the two countries provide distinct profiles. While several central and eastern European Union member states have higher rates of population decrease - such as Croatia, Bulgaria, and the Baltic states - it is Hungary where the phenomenon of population loss has been present for the longest time, since the early 1980s (Monostori et al. 2015). In contrast, Czechia is one of three Central European countries - together with Slovakia and Slovenia - that still have positive population dynamics (EC 2015) driven by immigration from other countries.

Although the national demographic characteristics might differ, intra-country differences reveal structural similarities. Age structure indicators or the share of old and young age groups, demonstrate small differences between Czechia and Hungary (see Tables 9 and 10). The terciles of previous analyses' component values decompose the overall trends into specific territorial tendencies. While higher constraints regarding labour markets are associated with a higher share of older age groups in both Czechia and Hungary, the share of the population younger than age 15 is only higher in areas of Hungary that are more vulnerable to the socioeconomic disadvantage index. Regarding the index representing poverty and social exclusion, poor performance in the underlying indicators seems to be insignificant in shaping the age structure in Czechia, while the Hungarian figures indicate a higher vulnerability to poverty and exclusion that parallels a lower share of older age groups and a significantly higher share of younger age groups. This potentially signals the Roma population's disadvantaged position.

Female/male ratios in the 20- to 30-year age groups are generally higher in Czechia than in Hungary. The overall figures demonstrate that typically fewer women than men are in these age groups in both countries. The only exception relates to the group of areas in Czechia with low labour market constraints, as this group has a higher ratio of females in the population. This underlines the sex-selective nature of mobility by noting the higher mobility of women in younger age groups (Leibert 2016), and especially when facing labour market constraints. In Hungary, both components of socioeconomic disadvantage reveal that while female/male ratios in the 20- to 30-year age groups might be higher in areas with better performance, this is also true of the groups of areas with the highest disadvantage regarding labour market constraints or vulnerabilities to poverty and social exclusion (see Tables 9 and 10).

Regional Statistics, Vol. 8. No. 2. 2018: 19-45; DOI: 10.15196/RS080204 
Two faces of peripherality: labour markets, poverty, and population dynamics in Hungary and Czechia

Table 9

Mean values of demographic variables in different areas according to the terciles of the composite index 'constrained labour markets', 2011

\begin{tabular}{|c|c|c|c|c|c|c|}
\hline Area category & $\begin{array}{c}\text { Share of } \\
\text { inhabitants } \\
\text { aged } 65+, \%\end{array}$ & $\begin{array}{l}\text { Share of } \\
\text { inhabitants } \\
\text { younger } \\
\text { than } 15, \%\end{array}$ & $\begin{array}{c}\text { Female/ } \\
\text { male ratio } \\
\text { in the } 20- \\
\text { to } 30 \text {-year } \\
\text { age groups, } \\
\%\end{array}$ & $\begin{array}{c}\text { Relative } \\
\text { population } \\
\text { change, } \\
\text { 2001-2011, } \\
\%\end{array}$ & $\begin{array}{c}\text { Average } \\
\text { yearly rate of } \\
\text { natural in- } \\
\text { crease, } 2001- \\
\text { 2011, 1,000 } \\
\text { inhabitants }\end{array}$ & $\begin{array}{c}\text { Average } \\
\text { yearly gross } \\
\text { migration } \\
\text { rate, } 2001- \\
2011,1,000 \\
\text { inhabitants }\end{array}$ \\
\hline \multicolumn{7}{|c|}{ Czechia } \\
\hline Well-performing & 15.2 & 15.6 & 101.7 & 18.8 & -0.5 & 15.7 \\
\hline Average & 16.0 & 15.0 & 98.4 & 6.2 & -1.4 & 6.8 \\
\hline Poorly performing & 16.7 & 14.5 & 95.8 & 2.7 & -2.2 & 4.2 \\
\hline \multicolumn{7}{|c|}{ Hungary } \\
\hline Well- performing & 17.5 & 14.8 & 92.3 & 0.4 & -5.4 & 5.7 \\
\hline Average & 18.0 & 15.1 & 89.6 & -7.9 & -6.7 & -1.2 \\
\hline Poorly performing & 18.7 & 15.8 & 93.6 & -11.9 & -6.9 & -5.1 \\
\hline
\end{tabular}

Table 10

Mean values of demographic variables in different areas according to the terciles of the composite index 'poverty and social exclusion', 2011

\begin{tabular}{|c|c|c|c|c|c|c|}
\hline Area category & $\begin{array}{c}\text { Share of } \\
\text { inhabitants } \\
\text { aged } 65+, \%\end{array}$ & $\begin{array}{l}\text { Share of } \\
\text { inhabitants } \\
\text { younger } \\
\text { than } 15, \%\end{array}$ & $\begin{array}{c}\text { Female/ } \\
\text { male ratio } \\
\text { in the } 20- \\
\text { to } 30 \text {-year } \\
\text { age groups, } \\
\%\end{array}$ & $\begin{array}{c}\text { Relative } \\
\text { population } \\
\text { change, } \\
\text { 2001-2011, } \\
\%\end{array}$ & $\begin{array}{c}\text { Average } \\
\text { yearly rate of } \\
\text { natural in- } \\
\text { crease, } 2001- \\
\text { 2011, 1,000 } \\
\text { inhabitants }\end{array}$ & $\begin{array}{c}\text { Average } \\
\text { yearly gross } \\
\text { migration } \\
\text { rate, 2001- } \\
2011,1,000 \\
\text { inhabitants }\end{array}$ \\
\hline \multicolumn{7}{|c|}{ Czechia } \\
\hline Low exclusion & 15.9 & 15.4 & 99.6 & 12.9 & -0.9 & 11.1 \\
\hline Average exclusion & 16.2 & 14.9 & 98.2 & 8.6 & -1.5 & 8.5 \\
\hline High exclusion & 15.7 & 14.9 & 98.3 & 6.2 & -1.7 & 7.2 \\
\hline \multicolumn{7}{|c|}{ Hungary } \\
\hline Low exclusion & 18.1 & 14.0 & 92.0 & -0.3 & -6.2 & 5.9 \\
\hline Average exclusion & 18.9 & 14.0 & 91.0 & -9.0 & -7.5 & -1.4 \\
\hline High exclusion & 16.8 & 17.9 & 93.2 & -10.1 & -4.8 & -5.3 \\
\hline
\end{tabular}

Regional Statistics, Vol. 8. No. 2. 2018: 19-45; DOI: 10.15196/RS080204 
The population change - such as a natural increase or decrease, or migration indicates a significant interrelationship with the analysed peripheralisation factors. The investigation of the population dynamics between 2001 and 2011 reveals that Czechia's overall population increase and Hungary's overall population decrease were incredibly selective depending on the regions' socioeconomic status. As anticipated, these demographic trends are more positive in groups of municipalities with fewer disadvantages in both labour market constraints and poverty and social exclusion. Somewhat opposite trends characterise the Hungarian municipalities regarding their rates of natural population change. In this case, groups of areas with the lowest values of natural decrease face the highest exclusion. These areas often overlap with concentration of the Roma population, in which birth rates and the ratio of children in the total population are often higher (Pénzes et al. 2013).

\section{Discussion and conclusions}

The development of peripheries in Czechia and Hungary does not correspond without difficulties to the German peripheralisation model, defined as mutually reinforcing economic and social problems and demographic decline. The analyses confirm that the peripheralisation processes proceed in a distinctly differentiated way in Hungary and Czechia. On the one hand, both countries include territories with constrained labour markets, located in rural areas with poor transport accessibility. Struggling rural communities tend to have low-qualification inhabitants, few skilled jobs, and lower income levels, and economically depend on agriculture at above-average levels. The accessibility problem is more urgent in Hungary than in Czechia, as the former has larger rural areas with poor access, while the latter has a denser, more evenly distributed network of small towns that partially eliminates any accessibility problems. On the other hand, the nature of peripherality differs between Hungary and Czechia. Czech rural areas with constrained labour markets are distinctly separated spatially from areas affected by poverty and social exclusion. Poverty, unemployment and social exclusion are not predominantly rural problems in Czechia, and do not strongly relate to poor accessibility. On the contrary, a majority of the affected territories are located in highly urbanised regions, which previously were economically oriented to heavy industry. In contrast, Hungary's rural areas with constrained labour markets more highly overlap with areas of social exclusion. The concurrent impact of labour market-related problems, poverty and social problems has led to the emergence of areas with complex issues, in which such socioeconomic problems meet the risk of transport-related exclusion. In light of these findings, Bernard and Šimon's (2017) argument regarding the existence of periphery types differentiated according to their prevailing social problems seems to be more valid for the Czech case.

Regional Statistics, Vol. 8. No. 2. 2018: 19-45; DOI: 10.15196/RS080204 
The population dynamics in both countries are unevenly spatially distributed and clearly differentiated according to peripheralisation indicators; however, Czechia's population is not decreasing due to the nation's overall population growth, even in communities suffering from economic and social issues. Rather, a population stagnation has occurred in such municipalities. In Hungary, the periphery has experienced a clear depopulation process, primarily due to migration. Further, evidence exists of increased ageing among both countries' peripheries, although a relatively modest natural decrease due to higher birth rates has limited further ageing in Hungary's peripheries.

In conclusion, Hungary's peripheralisation more highly corresponds to the idea of interrelated and mutually reinforcing economic peripheralisation processes. These manifest as limited job supply in the labour market, an accumulation of poverty and social problems, and population shrinkage, which particularly affect remote rural localities. Several differences exist in the how two countries' peripheralisation has developed.

First, one important difference arises from both countries' historically formed settlement structures. Although both Hungary and Czechia have similar degrees of urbanisation, they differ in their rural municipalities' accessibility and their economic interconnections with cities. Czechia has a dense network of small and mediumsized towns that provide jobs and services for rural inhabitants. Such a network covers a majority of the Czech territory, while a similar condition applies to only part of the Hungarian countryside. In many of Hungary's rural areas, access to urban centres is more demanding, and daily commuting is not a reasonable economic strategy for their residents. The mutual enhancement of peripheralisation factors typically occur in such locales, resulting in the development of 'disconnected' rural areas (Lennert 2017) with co-mingled social and economic problems.

Second, distinct spatial patterns of ethnic composition have influenced the forms of peripheralisation. The Roma are among the most vulnerable groups in both countries in terms of social exclusion (Revenga et al. 2002, Sirovátka-Mareš 2006), the Roma population lives predominantly in urbanised areas in Czechia as a result of communist-era industrialisation and resettlement policies. The Roma in Hungary are primarily concentrated in rural, often inaccessible areas. Thus, the ethnic and spatial aspects of social exclusion reinforce each other and contribute to the rise of social problems in the peripheral countryside (Brown-Schafft 2003).

Third, differences in both countries' overall demographic development explain their diverse peripheralisation processes. In particular, Czechia's economic and social disadvantages are not accompanied by a marked population decline. The country's overall population growth and its population's strong tendency towards spatial deconcentration as documented by Šimon and Bernard (2016) and Ouředníček et al. (2013) have caused peripheral areas to stagnate in terms of population development.

Regional Statistics, Vol. 8. No. 2. 2018: 19-45; DOI: 10.15196/RS080204 
In contrast, Hungary's long-term population decline is strong in disadvantaged peripheral areas.

This study illuminates the situation in the two countries while contributing to a more general question, focused on the extent to which peripheralisation processes are contextually dependent. Despite the fact that Czechia and Hungary share many structural similarities, have experienced similar political and historical developments in recent decades, and have similar economic situations, the two countries have far from identical spatial development, with remarkably distinct peripheralisation processes.

\section{REFERENCES}

ALPEK, B.L.-TÉsITS, R.-BOKOR, L. (2016): Group-specific analysis of commuting in the most disadvantaged areas of Hungary. Regional Statistics, 6(1), 54-81. https://doi.org/10.15196/RS06104

BAŃSKI, J. (2005). Suburban and peripheral rural areas in Poland: The balance of development in the transformation period. Geograficky Casopis Slovenskej Akademie Vied, 57(2), 117-130.

BArlÖsIUS, E.-NeU, C. (2008). Territoriale Ungleichheit: Eine spezifische Ausprägung räumlicher Untergleichheit. Zukunftsorientierte Nutzung ländlicher RäumeLandInnovation, 17.

BernARd, J.-DeCKER, A.-MIKEŠOVÁ, R.-VojTíšKovÁ, K. (2016): Living and Dealing with Limited Opportunities: Social Disadvantage and Coping Strategies in Rural Peripheries. Sociálni studia/ Social Studies, 13(2), 29-53.

BERNARD, J.-ŠIMON, M. (2017). Vnitřní periferie v Česku: Multidimenzionalita sociálního vyloučení ve venkovských oblastech. Sociologickéy casopis / Sociologický casopis. Cžech Sociological Review, 53(1), 3-28. https://doi.org/10.13060/00380288.2017.53.1.299

BIHARI, Zs.-KovÁCS, K. (2005): Slopes and Slides: Spatial Inequalities in Employment Opportunities at the Turn of the Millennium. In: Barta, Gy.-G. Fekete, E.Szörényiné Kukorelli, I.-Timár, J. (Eds.): Hungarian Spaces and Places: Patterns of Transition, Pécs, Centre for Regional Studies, 360-377.

BRown, D. L.-SCHAFFT, K. A. (2003): Social Exclusion in Rural Areas of Central and Eastern Europe. Eastern European Countryside, 1, 27-44.

BRyNIN, M.-LONGHI, S. (2009): Overqualification: Major or minor mismatch? Economics of Education Review, 28(1), 114-121.

EgRI, Z.-TÁNCZOS, T. (2015): Spatial Layers and Spatial Structure in Central and Eastern Europe. Regional Statistics, 5(2), 34-61. https://doi.org/10.15196/RS05203

European Commission (EC) (2015): Demography Report. Short Analytical Webnote, 3/2015. Luxembourg: Publications Office of the European Union.

Eurostat (2011): EU legislation on the 2011 Population and Housing Censuses. Explanatory Notes. Methodological and working paper series. Luxembourg: Publications Office of the European Union.

GorZelak, G.-Jatowiecki, B.-KukLinski, A.-Zienkowski, L. (1995): Eastern and Central Europe 2000, Luxembourg: European Commission.

Regional Statistics, Vol. 8. No. 2. 2018: 19-45; DOI: 10.15196/RS080204 
HAMPL, M. (2007): Regionální diferenciace současného socioekonomického vývoje v České republice. Sociologický časopis/Czech Sociological Review, 43(5), 889-910.

HARDI T. (2015): A munkaügyi ingázás területi mintái Észak-Dunántúlon. Területi Statisztika, 18(2), 122-141.

Kanalas, I.-KISS, A. (EDS.) (2006): A perifériaképzódés típusai és megjelenési formái Magyarországon. MTA RKK Alföldi Tudományos Intézet, Kecskemét.

KEARnS, A.-GIBB, K.-MACKAY, D. (2000): Area deprivation in Scotland: a new assessment. Urban Studies, 37(9), 1535-1559. https://doi.org/10.1080/00420980020080251

KeIM, K.-D. (2006): Peripherisierung ländlicher Räume — Essay. Aus Politik und Zeitgeschichte, 37(6), 3-7.

Koós, B. (2015): A szegénység és depriváció a magyar településállományban az ezredfordulót követôen - avagy kísérlet a települési deprivációs index létrehozására. Tér és Társadalom, 29(1), 53-68. https://doi.org/10.17649/TET.29.1.2681

KÜHN, M. (2015): Peripheralization: theoretical concepts explaining socio-spatial inequalities. European Planning Studies, 23(2), 367-378. https://doi.org/10.1080/09654313.2013.862518

LEIBERT, T. (2013): The Peripheralization of Rural Areas in Post-Socialist Central Europe. A Case of Fragmenting Development? Lessons for Rural Hungary. In: FischerTahir, A.-Naumann, M. (Eds.): Peripheralization. The Making of Spatial Dependencies and Social Injustice. Wiesbaden: Springer, 101-120. https://doi.org/10.1007/9783-531-19018-1_5

LEIBERT, T. (2016): She leaves, he stays? Sex-selective migration in rural East Germany. Journal of Rural Studies 43, 267-279. https://doi.org/10.1016/j.jrurstud.2015.06.004

LEIBERT, T.-GolinsKI, S. (2016): Peripheralisation: the missing link in dealing with demographic change? Comparative Population Studies - Zeitschrift für Bevölkerungswissenschaft, 41(3-4), 1-30.

LENNERT, J. (2017): Rural restructuring in the Visegrad Group - some geographical aspects, Ph.D. dissertation, University of Szeged, Faculty of Science and Informatics, Doctoral School of Geosciences, Department of Economic and Social Geography.

Madanipour, A.-ShuCKSmith, M.-TAlbot, H. (2015): Concepts of poverty and social exclusion in Europe. Local Economy, 30(7), 721-741. https://doi.org/10.1177/0269094215601634

Messer, L. C.-Laraia, B. A.-Kaufman, J. S.-Eyster, J.-Holzman, C.-Culhane, J.O'CAMPO, P. (2006). The development of a standardized neighborhood deprivation index. Journal of Urban Health, 83(6), 1041-1062. https://doi.org/10.1007/s11524-006-9094-x

Monostori, J.-Öri, P.-SPÉder, Zs. (Eds.) (2015): Demographic Portrait of Hungary 2015. Budapest: HDRI, 211-224.

MusIL, J.-MÜLLER, J. (2008): Vnitřní periferie v České republice jako mechanismus sociální exkluze. Sociologický časopis/Czech Sociological Review, 44(2), 321-348.

MyRDAL, G. (1957): Economic Theory and Under-developed Regions. London: Gerald Duckwords.

Regional Statistics, Vol. 8. No. 2. 2018: 19-45; DOI: 10.15196/RS080204 
NAgY, E.-NAGY, G.-DudÁs, G. (2015a): The uneven transformation of consumption spaces and the rise of new marginalities in Hungary. Regional Statistics, 6(2), 149-172. https://doi.org/10.15196/RS06208

NAgy, E.-Timár, J.-NAGY, G.-Velkey, G. (2015b): A társadalmi-térbeli marginalizáció folyamatai a leszakadó vidéki térségekben. Tér és Társadalom, 29(1), 35-52. http:/ /dx.doi.org/10.17649/TET.29.1.2680

Nemes Nagy J. (1996): Centrumok és perifériák a piacgazdasági átmenetben. Földrajzi Közlemények, (44)1, 31-48.

Nolte, H. H. (1991): Internal Peripheries in European History, Göttingen: Musterschmidt.

NovÁK, J.-P. NeTRdovÁ, P. (2011): Prostorové vzorce sociálně-ekonomické diferenciace obcí v České republice. Sociologický ociologick e obcSociological Review, 47(4), 717-744.

Novotný, L.-Mazur, M.-EgEdy, T. (2015): Definition and delimitation of peripheries of Visegrad countries. Studia Obszarów Wiejskich, 39, 35-48. https://doi.org/10.7163/SOW.39.3

OUŘEDNíČEK, M.-FEŘTROVÁ, M.-ŠPAČKOVÁ, P. (2011): Změny sociálního prostředí a kvality života $\mathrm{v}$ depopulačních regionech České republiky. Sociologický časopis / Czech Sociological Review, 47(4), 777-804.

OUŘEDNíČEK, M.-NOVÁK, J.-ŠIMON, M. (2013): Současné změny migrační bilance nejmenších českých obcí. In Výroční konference České geografické společnosti. Nové výzvy pro geografii. Brno: Masarykova Univerzita, 246-255.

PÁLÓCZI, G. (2016): Researching commuting to work using the methods of complex network analysis. Regional Statistics, 6(1), 3-22. https://doi.org/10.15196/RS06101

PÉnZES, J. (2013a): The Dimensions of Peripheral Areas and Their Restructuring in Central Europe. Hungarian Geographical Bulletin, 62(4), 373-386.

PÉNZES, J. (2013b): A foglalkoztatottság, az ingázás és a jövedelmi szint összefüggései Északkelet- és Északnyugat-Magyarországon. Területi Statisztika, 53(3), 202-224.

PÉnZES, J.-PÁszTOR, I.-TÁTrAI, P. (2013): Demographic processes of developmentally peripheral areas in Hungary. Stanovnistvo, 53(2), 87-111. https://doi.org/10.2298/STNV1502087P

PósfaI, Zs.-NAGY, G. (2017): Crisis and the Reproduction of Core-Periphery Relations on the Hungarian Housing Market. European Spatial Research and Policy, 24(2), 17-38. https://doi.org/10.1515/esrp-2017-0007

Revenga, A.-Ringold, D.-Tracy, W. M. (2002): Poverty and ethnicity: A cross-country study of Roma poverty in Central Europe. The World Bank.

ŠIMON, M. (2017): Multi-scalar geographies of polarisation and peripheralisation: A case study of Czechia. Bulletin of Geography. Socio-economic Series 37(3), 125-137.

ŠIMON, M.-Bernard, J. (2016): Rural Idyll without Rural Sociology? Changing Features, Functions and Research of the Czech Countryside. Eastern European Countryside, 22(1), 53-68.

SirovátKa, T.-MAREŠ, P. (2006): Poverty, social exclusion and social policy in the Czech Republic. Social Policy \& Administration, 40(3), 288-303.

Steinführer, A.-ReicherT-SCHICK, A.-Mose, I.-GrabSKI-KIERON, U. (2016): European rural peripheries revalued? Introduction to this volume. In: Grabski-Kieron, U.-

Regional Statistics, Vol. 8. No. 2. 2018: 19-45; DOI: 10.15196/RS080204 
Two faces of peripherality: labour markets, poverty, and population dynamics in Hungary and Czechia

Mose, I.-Reichert-Schick, A.-Steinführer, A. (Eds.): European rural peripheries revalued: governance, actors, impacts. Münster: LIT, 2-27.

SÝKORA, L.-MuLÍČEK, O. (2009): The micro-regional nature of functional urban areas (FUAs): lessons from the analysis of the Czech urban and regional system. Urban Research \& Practice, 2(3), 287-307. https://doi.org/10.1080/17535060903319228

Turnock, D. (1996) Agriculture in Eastern Europe: Communism, the transition and the future, GeoJournal, 38(2), 137-149. https://doi.org/10.1007/BF00186661

VIRÁG, T. (2006): The regional ghetto, Review of Sociology, 12(1), 51-70. https://doi.org/10.1556/RevSoc.12.2006.1.5

Regional Statistics, Vol. 8. No. 2. 2018: 19-45; DOI: 10.15196/RS080204 